\title{
Quality of Life For Patients with Cerebrovascular Stroke
}

\author{
Amal Bakr Abo El-Ata ${ }^{1}$; Noha Mohammed Ibrahim²; Reham Himdan Mohammed \\ Mowed $^{3}$ \\ Assistant professor of medical, surgical nursing - Faculty of Nursing Port Said \\ University $^{l}$; Lecturer of Medical Surgical nursing - Faculty of Nursing - Port Said \\ University $^{2}$; B.Sc. Nursing, Faculty of Nursing - Banha University ${ }^{3}$
}

\begin{abstract}
Background: Cerebrovascular stroke (CVS) had poor quality of life (QOL). Quality of Life (QoL) assessment was an important part of the evaluation of stroke patients. Aim: assess quality of life for patients with cerebrovascular stroke Method: a descriptive research design was utilized. Setting: study was conducted in the inpatient Neurology department and outpatient clinical at, El-Azhar university hospital and Port Said general hospital. Subjects: A convenient sample of 150 adult patients with cerebrovascular stroke admitted to above mentioned settings were participating in the study.Tool: data were collected using two tools,tool one: A Stroke-Specific Quality of Life Scale, and tool two structured interviews: it includes two parts. Part one socio-demographic characteristics and part two medical histories. The results: about three quarters of the studied patients had a low total quality of life, there were statistically significant relation between patients' socio-demographic characteristics and their total quality of life . Conclusion: Most of studied patients had low quality of life. Recommendations: There is a clear need for periodic training sessions and assessments to improve the quality of life of patients suffering from stroke.
\end{abstract}

Key Words: cerebrovascular stroke, quality of life, patients 


\section{INTRODUCTION}

Cerebrovascular stroke is a sudden lack of blood supply to certain parts of the brain. It's result from a clot blocking the blood flow, narrowing of the cerebral arteries and the blood vessels. Stroke divided into ischemic and hemorrhagic (Prabhakar et al., 2014)

Stroke in Egypt is the highest rate in northern Egypt and in Cairo t. Stroke is a major health problem in developing countries the prevalence rate of stroke in Egyptian population was significantly higher than other Arab countries (Khedr et al., 2018).

Cerebrovascular stroke types are transient ischemic stroke (TIA) is known as medical emergencies, Ischemic is the most common form of a stroke $(80 \%)$, caused by a blood clot, Hemorrhagic strokes (also known as cerebral hemorrhages or intracranial hemorrhages) usually occur when a blood vessel in the brain explosion and bleeds into the brain. About 5\% of cases (Sabogal et al., 2016).

A stroke is the sudden appearance of weakness, numbness, paralysis, speech, aphasia, problems with vision and other manifestations of a sudden boycott of blood flow to a certain area of the brain (Mojtab et al, 2015). The main risk factor for stroke is high blood pressure, smoking, obesity, high blood cholesterol, diabetes mellitus, previous TIA, and atrial fibrillation (Amelia, 2017).

Diagnosis of cerebrovascular stroke begins with a complete history and physical assessment, including neurological examination. The time of the onset of stroke manifestations is important of assessment. Computed tomography (CT) is the first technique used to demonstrate the presence of hemorrhage, tumors aneurysm, ischemia, edema and tissue necrosis (Julia S, 2019).

Management of cerebrovascular stroke depends on the type of stroke. People with acute stroke or trance ischemic stroke (TIA) must have the chance, wherever possible, to make informed decisions about treatment, in cooperation with their health care professionals. Good communication between healthcare professionals and people with acute stroke or TIA, as well as their families and cares is essential (American Heart Association,2016).

Stroke effects and rehabilitation after stroke are usually evaluated by occupational health ratings and performance tests. However, the real life of stroke survivors is affected 
in many ways and cannot be fully described solely through health and functional status. It is possible to succeed its treatment in improving its natural function recovery, however pushing psychosocial problems (Katona, 2015).

Health education is an essential component of rehabilitation. The nurse provides education about stroke, its causes, prevention, and the process of rehabilitation. A physical therapy program can be useful, whether it takes place at home or in an outpatient program. Recent research has focused on techniques for the use of robots and the treatment of the movement induced by the constraints (Howard,2015).

The type of life (QOL) may actually be degraded rehabilitation after a stroke. The WHO points out that the overall view of the quality of life includes not only physical health, but also psychological health, social relations and environmental quality (Duncan,2000).

A stroke can lead to survival with permanent disability in physical, psychological and social functions. Dependency in daily life activities living emotional and psychological change status and deterioration in social communication can affect the type of life (QOL) of patients suffering from stroke changes the role of experience due to poor autonomy caused by difficulty in the performance of living activities Daily, as well as problems related to personal relationships, they also experience psychosocial maladjustment due to long-term stress and stress. Which reduces their ability to selfevaluate their QOL (Sabogal, 2016).

\section{Significance of study:}

Stroke is the third leading cause of death and disability in the United States, Europe and many developing countries. As, stroke is the main cause of functional disabilities, and $20 \%$ of survivors need institutional care after 3 months, and $15 \%$ to $30 \%$ become permanently disabled. Stroke is a life-changing event that affects not only the person who may be disabled, but the entire family and other caregivers (Adams, 2013).

A stroke affects his physical, mental, family and social function. Varying levels of restrictions on physical activity, central nervous system (CNS) damage may lead to dysphagia, cognitive and intellectual disorders. Stroke is a major health problem in 
developing countries and the prevalence of stroke in Egypt's governors is much higher than in other Arab countries. (Khedr et al, 2017). In addition AL-Azher University, New Damietta Hospital Neurology Department in Egypt, (2017) also, reported that about three hundred fifty patient were admitted due to stroke in one year.

\section{AIM OF STUDY:}

The present study aims to assess quality of life for patients with cerebrovascular stroke.

\section{SUBJECTS AND METHOD:}

\section{Research Design:}

A descriptive study design was utilized to conduct the study.

The present study was carried out in the inpatient neurology department and outpatient clinical at, El- Azhar university hospital and Port Said general hospital.

\section{Population and Sample:}

A convenient sample of adult patients with cerebrovascular stroke admitted to the above mentioned settings in time of data collection (six months). Starting from Septemer2018 up the end of February 2019.

Tool of data collection: Two tool was used for data collection.

\section{Tool one: Structure interview: It includes two parts}

Part one: Socio-demographic data: This part includes items related to sociodemographic data of study patients as (name, age, having sons, work, education level, marital status, living with, and income level).

Part two: It includes: Patient's medical history, Patients' habits, Patients' knowledge about cerebrovascular stroke.

Tool two: A Stroke-Specific Quality of Life Scale. This scale developed by Williams; Weinberger; Harris; Clark; and Biller 1999 to assess quality of life, translated into Arabic language by the researcher which contain 73 items that ask patient's about the effects of CVS and treat them on psychological, social and economic aspects of their daily living activities. Stroke-Specific Quality of Life Scale (SS-QOL) is a comprehensive measure of health-related quality of life in stroke patients. All (12 domains) of the SS-QOL were 
one-dimensional and divided into (12 questions). Regarding to mobility (8 question) about family role, (4 question) about energy, (9 question) about upper extremity function, (3 questions) about work productivity, (8quations) about mood, (8 questions) about selfcare, (7questions) about social roles, 4 questions about vision, 7questions about language, 4 questions about thinking and (4 questions) about personality, time required to fill this part of 10 to15 minutes through interviewing with the patient. Most domains were moderately correlated with similar domains of established outcome measures ( $\mathrm{r} 2$ range, 0.3 to 0.5$) .4$ Patients responded to items in each domain using a 5-point rating scale.

\section{Scoring system:}

The scoring system of quality of life scale, its ranged from 0 to 5, zero for no effect and five high effects. Scoring system of quality of life scale, it contains 75 items divided into 12 domains. Total score ranged from 0 to 375, low quality of life as score less than $60 \%$ (225) score and high quality of life equal and more than $60 \%$. A scoring system of knowledge, the patients answer were recorded as yes equal one score and no equal zero, the total score of knowledge is (7).Equal or more than $70 \%$ of patient responses was considered satisfactory knowledge, while less than $70 \%$ considered unsatisfactory.

\section{Operational design:}

The operational design includes preparatory phase, reliability, content validity, pilot study and field work.

\section{Preparatory phase:}

It includes reviews of related literature, different studies and theoretical knowledge of various aspects of the problems using books, research articles, internet, Periodicals and magazines and internet in order to develop the data collection tools.

\section{Content validity:}

Content validity was conducted to test the tools, for appropriateness, relevance, correction and clearance through a jury of eleven experts from faculty of nursing, medical- surgical nursing department Port Said University and nursing AlAzharUniversity. Juries were from different academic categories (3 assistant professors and 8 lecturers). Their opinions were elicited regarding the tools format, layout, consistency and scoring system. 


\section{Reliability:}

All domains demonstrated excellent internal reliability (Cronbach's a value for total quality of life 0.98 ).

\section{Pilot study:}

The pilot study was carried out on $10 \%$ of the total sample to test the feasibility of tools, to find out the possible problems that might face the researcher and interfere with data collection .It is also helps to estimate the time required to collect data. After conducting it, it was found that the sentences of tools were clear and relevant. The patients included in the pilot study were excluded from the sample. Some modifications were done with the tools such as delete the definition of stroke and Do you know the reasons for your stroke?

\section{Field work:}

The selection of patients (both male and female patients who were diagnosed with CVS were included), and collection of data lasted over a period for 6 months starting from September 2018 up the end of February 2019. Three days per week were specified for data collection at Al-Azhar University Hospital (New Damietta city) and Port Said general hospital.

After permission to conduct the study and finalization of tools, the researcher met patients individually and the purpose of the study were explained, oral consent of each eligible patient was obtained before their participation, techniques to assure and verify results. As regards to structure the interview at Al-Azhar University Hospital (New Damietta) and Port Said general hospital, the time used to filling the structured interview ranged from 20 to 30 minutes included interviewing the patient regarding sciodemographic characteristic, medical history and patient's life style, time used to filling SS-QOL ranged between 15-30 minute.

\section{Administrative design.}

An official letter from the faculty of Nursing Port-Said University was directed to the hospital's manager to obtain their permission to conduct the study. Written approvals were obtained from Al-Azhar University Hospital (New Damietta city) and Port Said general hospital administrators. 


\section{Ethical consideration}

- Oral consent will be taken from patients to participate in the study after explanation of the study aim.

- The researcher informs the study participant that they have the right to withdraw from the study at any time they wish to do without rationalization.

- The participants will be assured about confidentiality of information gathered and that will be used only for the purpose of the study.

\section{(IV) Statistical Design:}

Data entry and statistical analysis were done using the SPSS statistical software package (version 16). Data were presented using statistics in the form of frequencies and percentages for qualitative variables

Statistical measures were used:

Descriptive statistics including frequency, distribution, mean, and standard deviation were utilized t0 different characteristics.

The observed differences and association were considered as the following:

Significant (S) $\mathrm{p}<0.05$

\section{RESULTS:}

Table (1): the studied patients according to their Scio demographic characteristics, it shows that , $43.3 \%$ of the studied patients were aged equal 60 years old and more than one third $36 \%$ of them had a moderate level of education. Regarding to their occupation, two fifths $40 \%$ of they were housewives, also $60 \%$ of the studied patients were married and the majority $96 \%$ of them had sons. And slightly less than half, $46.7 \%$ of patients living with their partner finally most $86.7 \%$ of them had an average income level.

Table (2): distribution of the studied patients according to their quality of life. It demonstrates that more than three quarters $78.7 \%$ of the studied patients had low quality of life regarding energy and $92 \%$ of them had low quality of life regarding their family role. Also, $54.7 \%, 92 \%, 51.3 \%, 88.7 \%, 56.7 \%$ and $73.3 \%$ of the studied patients had low quality of life regarding domains of language, movement, self-care, social role, thinking and production respectively. While $55.3 \%, 54.7 \%, 70 \%$ and $70 \%$ had a high quality of life regarding domains of mood factors, personality, function of upper extremities and 
vision respectively. Finally, this table clarifies that, three quarters $75.3 \%$ of the studied patients had a total low quality of life.

Figure (1): Distribution of the studied patients according to their total quality of life. This figure displays that, most of the studied patients $75.3 \%$ had low quality of life regarding stroke.

Table (3): relation between social, demographic characteristics of patients and their total quality of life. It indicates that there were statistically significant relation between patients' socio-demographic characteristics and their total quality of life $(p=000)$. 
Table (1): The studied patients according to their sciodemographic characteristics $(n=150)$

\begin{tabular}{|c|c|c|}
\hline Item & Frequency (n) & Percentage $(\%)$ \\
\hline \multicolumn{3}{|l|}{ Age / years } \\
\hline$<30$ & 4 & 2.7 \\
\hline $30<40$ & 18 & 12.0 \\
\hline $40<50$ & 16 & 10.7 \\
\hline $50<60$ & 47 & 31.3 \\
\hline$=60$ & 65 & 43.3 \\
\hline Mean \pm SD & \multicolumn{2}{|l|}{$56.2 \pm 12.5$} \\
\hline Educational level & & \\
\hline Illiterate & 38 & 25.3 \\
\hline Read and write & 40 & 26.7 \\
\hline Moderate level & 54 & 36.0 \\
\hline University & 18 & 12.0 \\
\hline \multicolumn{3}{|l|}{ Occupation } \\
\hline Work & 54 & 36.0 \\
\hline Retired & 20 & 13.3 \\
\hline Housewife & 60 & 40.0 \\
\hline Not work & 16 & 10.7 \\
\hline \multicolumn{3}{|l|}{ Type of work $(n=54)$} \\
\hline Teacher & 7 & 12.9 \\
\hline Carpenter & 15 & 27.8 \\
\hline Accountant & 10 & 18.5 \\
\hline Worker & 9 & 16.7 \\
\hline Engineer & 2 & 3.7 \\
\hline Smith & 1 & 1.9 \\
\hline Electrician & 1 & 1.9 \\
\hline Fisher man & 2 & 3.7 \\
\hline Employee & 5 & 9.2 \\
\hline Farmer & 2 & 3.7 \\
\hline
\end{tabular}


Table (1): The studied patients according to their sciodemographic characteristics. continue

\begin{tabular}{|l|l|l|}
\hline Item & $\mathbf{n}$ & \% \\
\hline Marital status & \multicolumn{2}{|l|}{} \\
Single & 6 & 4.0 \\
Married & 90 & 60.0 \\
Widowed & 54 & 36.0 \\
\hline Having sons & & \\
Yes & 144 & 96.0 \\
No & 6 & 4.0 \\
\hline Number of sons (n=144) & & \\
$1-3$ & 76 & 52.8 \\
$4-6$ & 68 & 47.2 \\
\hline Mean \pm SD & $3 \pm 1.2$ & \\
\hline Living with & 70 & 46.7 \\
Partner & 60 & 40.0 \\
Sons & 2 & 1.3 \\
Relatives & 4 & 2.7 \\
Parents & 14 & 9.3 \\
Husband and sons & 20 & \\
\hline Income level & 130 & \\
Enough & \multicolumn{2}{|l|}{} \\
Not enough & 6.7 \\
\hline
\end{tabular}


Table(2): Distribution of the studied patients according to their quality of life $(n=150)$

\begin{tabular}{|l|l|l|l|l|}
\hline \multirow{2}{*}{ Item } & \multicolumn{2}{l}{ Low Quality of Life } & \multicolumn{2}{l|}{ High Quality of Life } \\
\cline { 2 - 5 } & $\mathrm{n}$ & $\%$ & $\mathrm{~N}$ & $\%$ \\
\cline { 2 - 5 } & & & & \\
\hline Energy & 118 & 78.7 & 32 & 21.3 \\
\hline Family role & 138 & 92.0 & 12 & 8.0 \\
\hline Language & 82 & 54.7 & 68 & 45.3 \\
\hline Movement & 138 & 92.0 & 12 & 8.0 \\
\hline Mood factors & 67 & 44.7 & 83 & 55.3 \\
\hline Personality & 68 & 45.3 & 82 & 54.7 \\
\hline Self -care & 77 & 51.3 & 73 & 48.7 \\
\hline Social role & 133 & 88.7 & 17 & 11.3 \\
\hline Thinking & 85 & 56.7 & 65 & 43.3 \\
\hline Function of upper extremities & 45 & 30.0 & 105 & 70.0 \\
\hline Vision & 45 & 30.0 & 105 & 70.0 \\
\hline Production & 110 & 73.3 & 40 & 26.7 \\
\hline
\end{tabular}

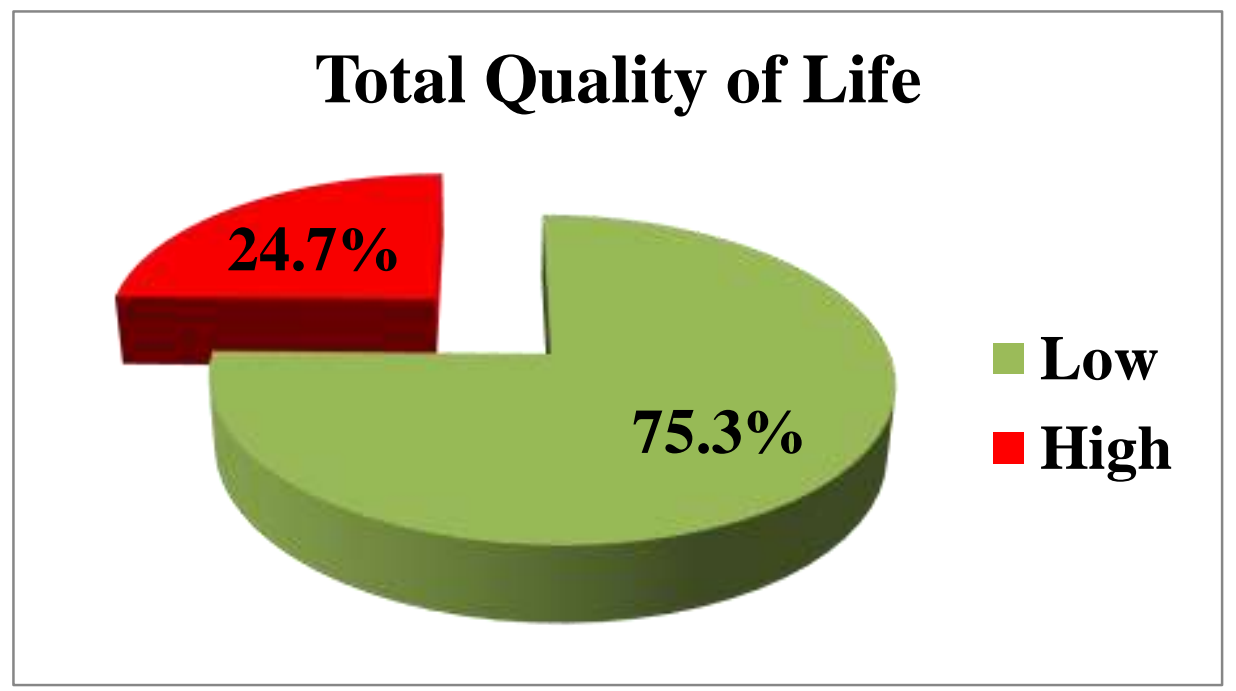

Figure (1): Distribution of the studied patients according to their total quality of life 
Table (3): relation between social, demographic characteristics of study patients and their total quality of life:

\begin{tabular}{|c|c|c|c|c|c|c|}
\hline \multirow{3}{*}{ Item } & \multicolumn{4}{|c|}{ Total quality of life } & \multirow{3}{*}{$\mathbf{X}^{2}$} & \multirow{3}{*}{ P-value } \\
\hline & \multicolumn{2}{|c|}{ Low } & \multicolumn{2}{|c|}{ High } & & \\
\hline & $\mathbf{n}$ & $\%$ & $\mathrm{n}$ & $\%$ & & \\
\hline \multicolumn{7}{|l|}{ Age/ years } \\
\hline$<30$ & 4 & 100 & $\mathbf{0}$ & 0.0 & & \\
\hline $30<40$ & 7 & 38.9 & 11 & 61.1 & & \\
\hline $40<50$ & 6 & 37.5 & 10 & 62.5 & 40.79 & .000 \\
\hline $50<60$ & 34 & 72.3 & 13 & 27.7 & & \\
\hline$=60$ & 62 & 95.4 & 3 & 4.6 & & \\
\hline \multicolumn{7}{|l|}{ Education } \\
\hline Illiterate & 37 & 97.4 & 1 & 2.6 & 33.30 & .000 \\
\hline Read and write & 36 & 90.0 & 4 & 10.0 & 53.50 & . .000 \\
\hline Moderate level & 33 & 61.1 & 21 & 38.9 & & \\
\hline University & 7 & 38.9 & 11 & 61.1 & & \\
\hline \multicolumn{7}{|l|}{ Marital status } \\
\hline Single & 4 & 66.7 & 2 & 33.3 & & \\
\hline Married & 57 & 63.3 & 33 & 36.7 & 19.98 & .000 \\
\hline Widowed & 52 & 96.3 & 2 & 3.7 & & \\
\hline \multicolumn{7}{|l|}{ Work } \\
\hline Work & 24 & 44.4 & 30 & 55.6 & & \\
\hline Retired & 19 & 95.0 & 1 & 5.0 & 44.07 & .000 \\
\hline House wife & 54 & 90.0 & 6 & 10.0 & & \\
\hline Not work & 16 & 100 & $\mathbf{0}$ & 0.0 & & \\
\hline \multicolumn{7}{|l|}{ Income level } \\
\hline Not enough & 108 & 83.1 & 22 & 16.9 & & \\
\hline \multicolumn{7}{|l|}{ Living with } \\
\hline Partner & 47 & 67.1 & 23 & 32.9 & & \\
\hline Sons & 58 & 96.7 & 2 & 3.3 & & \\
\hline Relatives & $\mathbf{0}$ & 0.0 & 2 & 100 & 41.11 & .000 \\
\hline Parents & 4 & 100 & $\mathbf{0}$ & 0.0 & & \\
\hline Husband and sons & 4 & 28.6 & 10 & 71.4 & & \\
\hline \multicolumn{7}{|l|}{ Number of sons $(n=144)$} \\
\hline $1-3$ & 46 & 60.5 & 30 & 39.5 & 28.28 & .000 \\
\hline $4-6$ & 63 & 92.6 & 5 & 7.4 & & \\
\hline
\end{tabular}

\section{DISCUSSION:}

Cerebrovascular accidents (CVA) or stroke continues to be a serious neurological condition that threatens thousands of people every year, leading to death and morbidity worldwide (Fodor et al., 2018). 
It is also a causative factor for the long-term synthesis of disability such as balance deficiencies, perception deficiencies, aphasia, paralysis of some parts of the body, depression, and other alteration of the cognitive functions (Mozaffarian \& Benjamin, 2016).

The current study finding revealed that, higher percentage of them was equal 60 years. This result was supported by (Safaa A Mahran, 2015) who reported that, the average of patients under their study was the majority of the studied patients were aged equal 60 years old. In this study was more than third of them had moderate of education. A similar study was conducted by $\mathrm{Li}$ et al., ( $\mathrm{Li}$ et al, 2017) in China shown similar findings in terms of gender, residential status and education levels, also similar study by (Mabrouka, 2016), there were significant relation between patient's quality of life and age, education and living income.

In terms of working condition, we found two-fifths of them housewives and more than a third of the studied stroke patients were working people, of whom most patients worked more than ten hours a day. The risk of working with more than three quarters of stroke patients has been found. Therefore, it is quite clear that the risks of work and working hours can be moderate contributors to stroke.

The results of the study noted that about half of the participants were married. On the other hand, this results in the same line with (Jahroul, 2015; Ayşegül Çelik, 2016) who stated that more than one patient was married.

In this study the vast majority of patients who had children. Also slightly less than half of the patients living with their partner and most of them had an average income level. This result is supported by (Jung, 2015).

The study showed about three-quarters of the patients studied had a low quality of life in terms of energy, and the majority had low quality of life in relation to their family role. Also of the studying patients receive a high percentage of low-life species regarding fields of language, movement, self-level, social role, thinking and production respectively. These results are consistent with the results of several studies that have reported that stroke disability causes a decrease in QOL among stroke survivors, and the higher the disability, the lower the QOL study agreed with (CarodArtal, 2000), also by (Mabrouka, 2016) 
Our study findings, there were highly significant relation between patient's quality of life and daily living ,the current study matched with Lai et al, 2002 and Acta et al,2013 found that stroke causes sufficient decrease in the QOL even among those who have no post stroke disability, and patients with CVS had poor QOL the specific domains most affected in the study, which are those that could be triggered in the presence of the disease or its consequences, were: mobility, work, upper limb function, behavior, family and social relationships, and energy.

There was statistical significance relationship between the age, education, marital status, work, and the quality of their overall lives). It also noted that there is a statistically significant relationship between the patient's income level, living with the number of children and the quality of their overall life, and that elderly patients in the age group (5060 years) and 60 equal age are very vulnerable compared to younger patients ( $\mathrm{Na}$ Yun Gong, et al, 2017) Who showed the relations about age and QOL.

The results of the study were low educational level associated with the high rate of stroke, especially when combined with social, economic and cultural factors and difficulty in accessing information, in addition to reducing awareness of care Lethe, and commitment to treatment and maintaining my life, while higher education refers to increased survival, this finding was agreed with his study (Rangis, 2013). These results differed with the study conducted (Al-Shamaa et al., 2010) they studied the assessment of the needs of biopsychosocial patients suffering from chronic cerebrovascular stroke and our study is identical to (Helmiey, 2013), which found that the majority of the study married, illiterate and still working.

\section{CONCLUSION:}

Most of studied patients had a low total quality of life. And there were statistically significant relation between patients' socio-demographic characteristics and their total quality of life .

\section{RECOMMENDATION:}

There is a clear need for periodic training sessions and assessments to improve the quality of life of patients suffering from stroke. 


\section{REFERENCES:}

Amelia K, Boehme, Charles Esenwa, Mitchell S.V. Elkind,(2017): Stroke Risk Factors, and Prevention Original received November 30, 2016; revision received January 5, 2017; accepted January 5, 2017.

American heart association, (2016): Heart disease and stroke October 26, 2016 Vol 5, Issue 11. Published on behalf of the American Heart Association, Inc., by Wiley Blackwell.

Karakurt, P., Unsal, A., \& Tanriverdi, D. (2018). Evaluation of Care Burden and Quality of Life of Caregivers of Patients with Stroke. International Journal of Caring Sciences.

Figueiredo, J., Moreno, J. C., Matias, A. C., Pereira, F., \& Santos, C. P. (2019). Outcome measures and motion capture systems for assessing lower limb orthosis-based interventions after stroke: a systematic review. Disability and Rehabilitation: Assistive Technology, 1-10.

El-shamaa E, El- Banouby ., \& Mustafa, N,(2010): Assessment of biopsychosocial needs of patients with chronic cerebrovascular stroke. Thesis for Master Degree in Nursing Science, Medical Surgical Nursing, Faculty of Nursing, Ain Shams University, Egypt. Journal of Pharmaceutical and Biomedical Sciences, (1), (3), pp: 69-78.

Fodor K, Ţiţ DM, Paşca B, Buştea C, Uivaroşan D, Endres L, Iovan C, Abdel-Daim M, Bungău S, (2018): Long-term Resveratrol supplementation as a secondary prophylaxis for stroke. Oxide MED Cell Longev., 2018; 2018: 1-10.

Food abed-Allah, Eman Khedr, Mohammed I Oraby, Ahmed Safwat Bedair, Shady Samy Georgy \& Ramez Reda Moustafa, (2018): Burden of stroke in Egypt: current status and opportunities. The Atlas of Heart Disease and Stroke, 5051International Journal of Neuroscience, Volume 128, 2018 - Issue 8Published online: 04 Jan 2018.

Helmiey E, (2013): Needs and concerns for stroked patient at Benha University Hospital, Master Thesis, Faculty of Nursing, Benha University. P. 15. 
Howard, V. J., \& McDonnell, M. N, (2015): Physical activity in primary stroke prevention: Just Do It! Stroke, 46 (6), 1735-1739. https://doi.org/10.1161 /STROKE AHA. 115.006317

Jahirul, M. S, Choudhury, H., Chowdhury, T. I, \& Nayeem, A, (2015): Modifiable and nonmodifiable risk factors of stroke: A review, update, 1(1), 22-26

Jong S. Kim, M.D., Smi Choi-Kwon, Ph.D., R.N., Sun U. Kwon, M.D., Hee J. Lee, R.N., MSN, Kyung-Ae Park, Ph.D, Youn S. SEO, R.N, (2005: Factors Affecting the Quality of Life After Ischemic Stroke: Young Versus Old Patients Journal of Clinical Neurology/Volume 1/April, 2005.

Julia Shirvan, Nathan Clement, Rong Ye, Samantha Katz, Aaron Schultz, Keith A. Johnson, Teresa Gomez-Isla, Matthew Frosch, John H. Growdon, Stephen N, (2019): Gomperts Neuropathologic correlates of amyloid and dopamine transporter imaging in Lewy body disease First published June 26, 2019, DOI: https://doi.org/10.1212/WNL.0000000000007855 Second Edition Springer Nature Switzerland AG 2019.

Katona, M, Schmidt R, Schupp W, Graessel E, (2015): Predictors of health-related quality of life in stroke patients after neurological inpatient rehabilitation: a prospective study. Health Qual Life Outcomes 2015;13:5

Lee SM, Studenski S, Duncan PW, Perera S, (2002): Persisting consequences of stroke measured by the Stroke Impact Scale. Stroke 2002; 33 :1840-1844.

Li, Q., Wu, H., Yue, W., Dai, Q., Liang, H., Bian, H., ... Shen, Y. (2017). Prevalence of stroke and vascular risk factors in china: A nationwide community-based study. https://doi.org/10.1038/s41598-017-06691-1

Mabrouka Ahmed Abdella Mahmoud,(2016): Factors Affecting Quality of Life for Patients with Cerebrovascular Stroke Thesis for Master Degree in Nursing Science, Medical Surgical Nursing, Faculty of Nursing, Ain Shams University, Egypt.

Mozaffarian, D., Benjamin, E. J., Go, A. S., Arnett, D. K., Blaha, M. J., Cushman, M,Turner, M. B,(2016):Heart disease and stroke statistics-2016 update a report 
from the American heart association. Circulation (Vol. 133). https://doi. Org/10. 1161/ CIR.0000000000000350

Mojtaba Mahmoodi1, Anahid Safari2, Mehrdad Vossoughi3, Fatemeh GolbonHaghighi4, Maliheh Kamali-Sarvestani4, Haleh Ghaem5, Afshin BorhaniHaghighi6, (2015): Health Policy Research Center AND School of Medicine, Shiraz University of Medical Sciences, Shiraz, Iran: Iranian Journal of Neurology (C) 2015 Corresponding Author: Afshin Borhani-Haghighi Email: ijnl@tums.ac.ir Email: neuro.ab@gmail.com http://ijnl.tums.ac.ir 4 April.

Na Eun Jeon, MD, Kyoung Min Kwon, MD, Yeo Hyung Kim, MD, Jung Soo Lee, MD.(2017): The Factors Associated With Health-Related Quality of Life in Stroke Survivors Age 40 and Older: Received October 26, 2016; Accepted January 6, 2017.

Prabhakar S, Taranjeet K, Ashish T, (2014): Role of active components of Medicinal plants in Neurodegenerative disorders and Synaptic Plasticity, International Journal of ChemTech Research, 2014, 6: 982-984.

Range., S. S. Belasco., A. G. Sand Diccini, (2013): Quality of life of patients with stroke rehabilitation,SciELO.Sao Paulo, Brazil.26 (2).

Sabogal G, (2016): Health-related quality of life in stroke patient questionnaire, short version (HRQOLISP-40): validation for its use in Colombia. Available at https://bmcneurol.biomedcentral.com.Accessed on 28/3/2018.

Save A Marian MD, Mohamad A Abdulrahma, Fadwa S Janbi, Rawabi A Jamalellail. (2015): The health-related quality of life in stroke survivors: clinical, functional, and psychosocial correlates Date of Submission 03-May-2015 Date of Acceptance 01-Jun-2015 Date of Web Publication 26-Oct-2015. 


\section{جودة الحياة لمرضى السكتة الدماغية}

أمل بكر أبو العطا محمد ، نهى محمد إبراهيم، ريهام حمدان محمد معوض

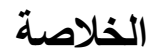

السكتة الدماغية ترتبط بسوء جودة الحياة ،وكان الهدف من خلال هذه الدراسة تقيم جودة الحياة لمرضى السكتة الدماغية ــ وأجريت هذه الدراسة الوصفية فى القسم الداخلى والعيادات الخارجية لقسم العصبية لمستشفى جامعة الازهر بمدينة دمياط الجديدة ومستشفى الأميرى ببورسعيد وقد اشتملت العينةعلى 150 مريض ونه ونم جمع البيانات

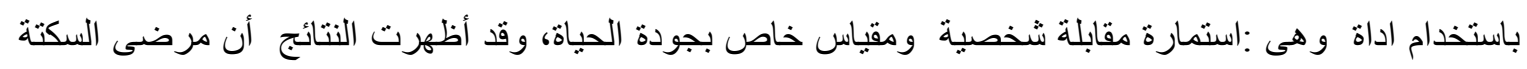
الدماغية يعانون من سوء جودة الحياة ، وكانت هناك علاقة بين سن المرضي الذين درسوا ، و التعليم ، والحالة

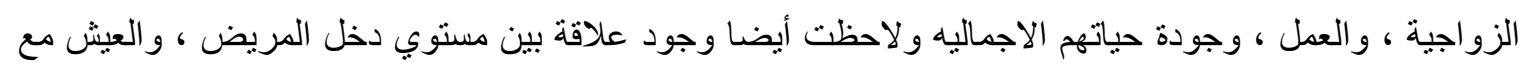

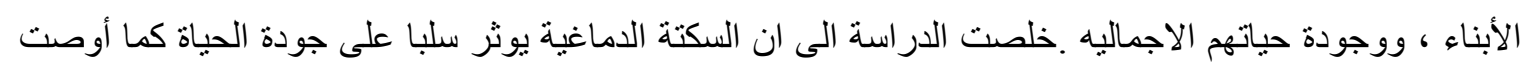
الدر اسة بتثقيف المرضى بخصوص التدخلات اللازمة لتحسين جودة الحياة.

الكلمات المرشدة : السكتة الدماغية ،جودة الحياة 